製品紹介

島津 S A 型自動ワイイン ダ

緒啇

叟津製仡所では数个前より自動ワインダの国撞をはか り試你研究が行われて来たが，今回完成したのでここに 紹介寸る。

木自動ワインダは杀結びを自動的に行うもので, 系結 び装置が定位置にあり, ワインデング ユニットが機械 の周囲を循環する形式のものである。

機棫の構造

第 1 図に機械の要領そ，第 2 図に操業中の機悈，第 3 , 4図にノッタ部, 第 5,6 図にワインデングュニ ットの正面, 第7図にノッタを示す。

ワインデング ユニットは第 5 図の如く、管糸 (1), テ ンション装置(2), クレードル(3)、ロートコーナ型ドラ ム(4)、チーズ(5)及びフイラ(6が朹(7)に取付けられたもの である、ドラムの後側にあって機械の長手方向に長く装 備された駆動ローラ（写真では見党ない）によりドラム は回転され卷取りを行いつつ, 無端チェンによりレール (8)，(9)を第1 四矢印の宁向に一定速展で巡回する.

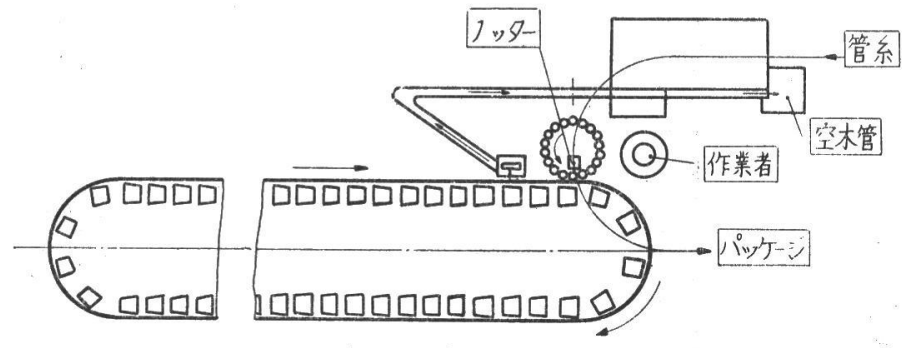

（第 1 図）

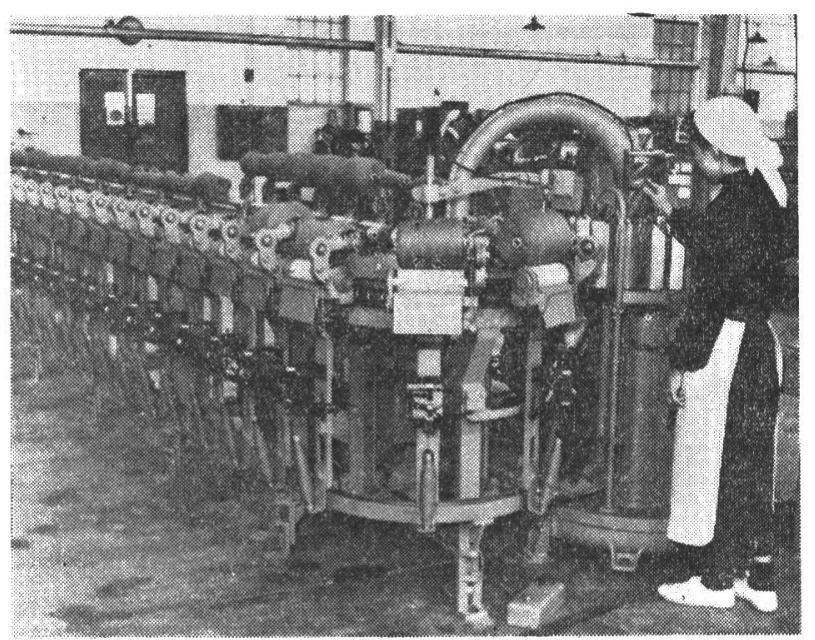

(第 2 网)

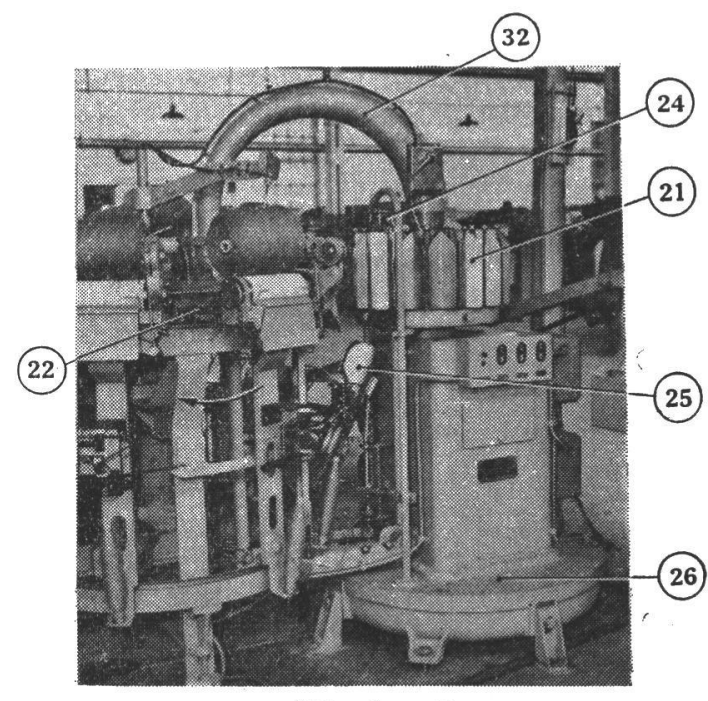

(第 3 図)

今作業を順を追って説明すると，作業者は定位置で管 系の糸口を出してマガジン 211補給する.マガジンは管 糸の待機用の容器で20本前後の管系が収納でき, 且つワ インデング ユニットがノッタ部に進入し てくる每に 1 ピッチまわされる・ワインデ ングユニットがノッタ部に進入してくる とチーズは逆転ローラ®に当り逆転し, 吸 引ノズル32により緛が見出される。この 糸端はノズルの胴部をわたってノッタ(24) 運ばれ，そこで待機している管系の緛と ノッタで自動的に結ばれる・その直後管系 はホッパ20亿によりペッグ(3に移される・ついでワィ ソデングニニットがまわって行き穖械の直線部の 駆動ローラのところまで来るとドラムが駆動され巻 取りが開始される. 更に進み機械の向端に達した時 は巻取中そのままの姿勢でまわり又直線部にくると 卷取りを継続する・糸切れの時はフイラが働きクレ ードルが起さてチーズはドラムから離れる．通常ワ インデングュニットが一巡する間に管糸は空にな るようになって扣り,ノッタ部に入る直前で空木管 (34)(途中糸切れしたものは系の残ったまま) は拔取 装㯰国で拢取られコンペアで木管受箱まで運ばれ る.な掠端吸引用のファンはヶース然内にある。

\section{機械の性 能}

1)系の結び方 フィッシャマンノット(てぐ 


\section{す結び)}

2)系結回数

3) 卷取速度

$10 \sim 22$ 回 $/ \mathrm{min}$

4) 鍾 数

$300 \sim 600 \mathrm{yd} / \mathrm{min}$

5)糸巻方法

$60 \sim 220$

6) パッケージの形状 コーン及びチーズ（5in又は

(32.)

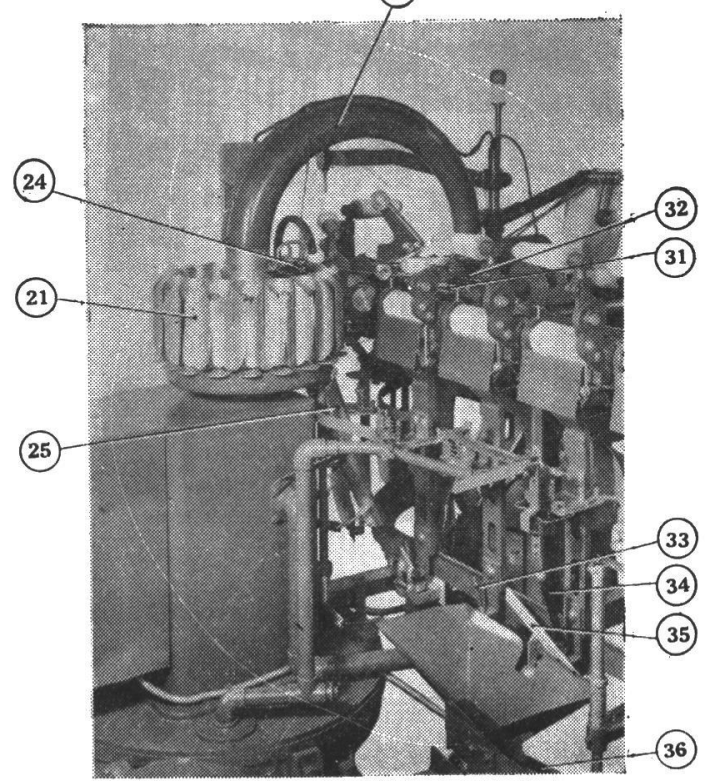

(第 4. 図)

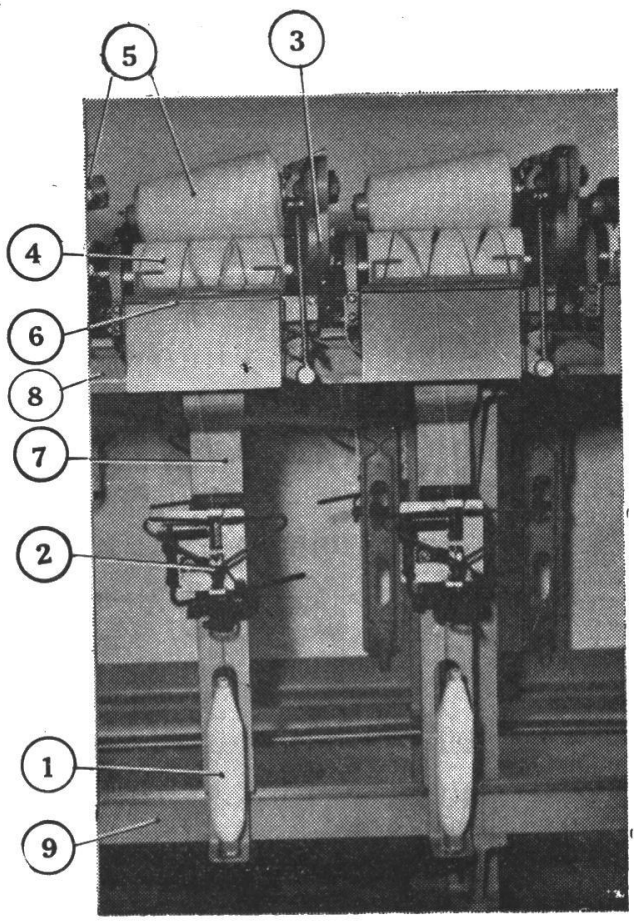

(第 55 図)
6 in 1.ラパース)

7)用途綿系, スフ糸, 混紡系, 羊毛系

8 ）使用系卷管 木管, 紙管

\section{本機の特長}

1) 作業者は管系をマガジンに大れ，糸端を吸引口に あてがうだけである。

2）管糸の補給もチーズの玉揚げも定位置でできる.

3) 系の結び方はフィッシャマンノット（てぐす結 び)で堅固で特に毛系には最適である.

4) ワインデング ユニットにはロートコーナ型ドラ ムを使用しているから構造が簡単であり，且つチ

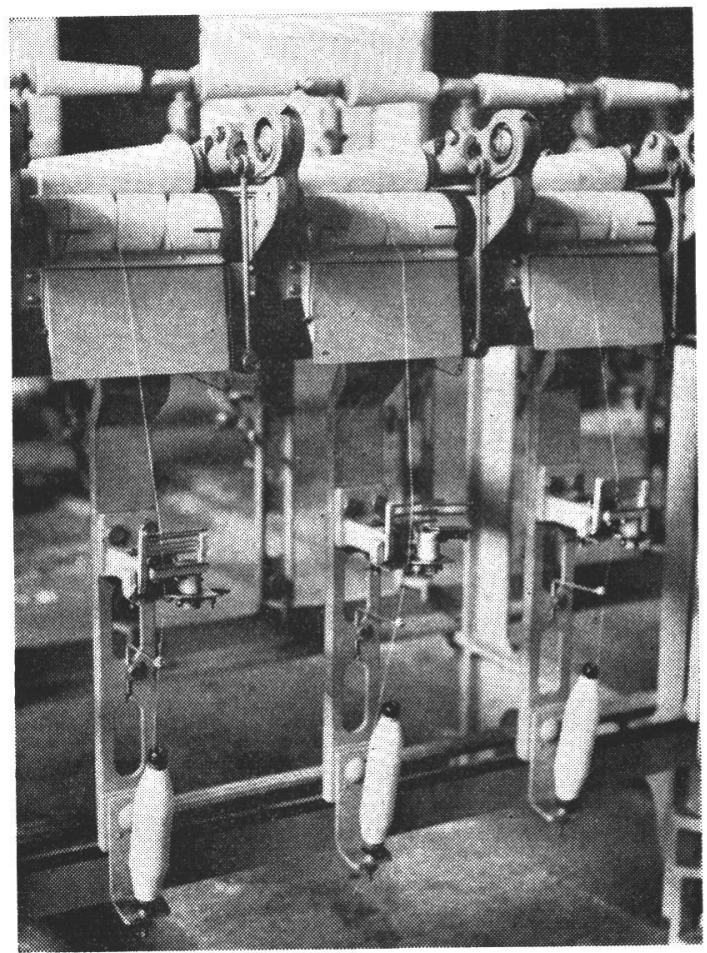

（第 6 図）

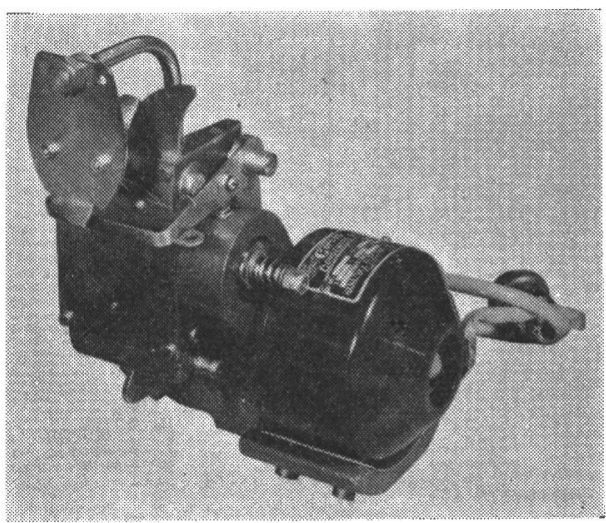

（第 7 図） 
ーズはドラムによりまわされ，駆動ローラには 接しないからワインデングュニットの進行によ り,チーズが駆動ローラの接目等で悪い影響を受 けることがない，且つ機械の端部でもチーズはド ラムに接したままでよいからチーズを上下寸る 操作も不用で又その際起き易い系のちぢれも防げ る.

5) ノッタ部に特殊な考案が施されているから綿系そ の他強撚の場合でも系にちちれを生じない。

6) テンション自動調整装置が必要に応じ附し得るの で羊毛系並びに双系む崩れずに卷ける。

7) ホッパは独特の構造になっており，管系はマガジ ンからペッグにミスなく移される。

8) 巻取速度及び巡回速度は無段変速プーリの使用に より容易に变速できる。

9) テンション及びスラブキャッチャ部の系屑及び フライの掃除は一巡每に完全に行われる.

10）系卷管は, スピンドルの取替えだけで紙管, 木管 いずれも使用でき，且つコーンでもパラレルチ ーズでも卷ける。

\section{機械の種類}

基本的な部分は同じであるが，部品及び附属品により 次の種類がある.

A) 綿系, スフ系, 混紡采用
(1) 系のち年れ防止のアタッチメントがついてい る.このアタッチメントはノッタで糸結びが行 われ系がノッタを離れた直媵一時紬かるんで ちちれが生ずるのを防止するるので，当社独特 の考案によるものである.

（2）テンションはゲート式（第6四参照）

(3) スラブ キャッチャは薄双式又は鋸蒌形式で ある. (第 6 四参照)

B) 羊毛系用

(1) テンションはワッシャ式或はダート式 (第 5,6 四参照)

(2) スラブキャッチャはプロック式（第 5 図参 照)

（3）張力自動調整装置が附属できる. 双系及び太 番手のもので卷上りが崩れるものは本装置によ り整形される。

（4）フリーパス萃置が附属できる・これはゲージ をよく効かして系の切断を多くした場合には機 械効率が下るのでこれを避けるため，ワインデ ングニニットが㙨㳦を二巡する間に管禾がな くなるよらに機械を短く（錘数を減らす）して おき，糸が切れないで卷取中のものはノッタ 部をそのままで通過するようにした装置であ る.

\section{経糸糊付東洋紡績深田要著}

\section{A 5 版 140頁 特上製クロス装幀 定洒 300円 書留送料 70円}

織布工場に执いて準備工程の中でも，特に経糸糊付竹業がもっとも主要な工程で，糊付作業の良否が織機室の能 率製品の品質を左右する.

本畫は糊付の現場技術者或は織布技術者として是非とも知っておくべきことを極めて実際的に且つ平易に記述さ れており，読んで直ぐ役に立つことを目標とされたものである・故に紡績会社の織布技術者はもちろん，織布事業 の糊付現場担当者に至る迄必携の憲であると信ずる.

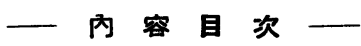

1. ま がき

2. 経系糊付の目的

3. 糊付系として具倩すべき条件

4. 経系糊として必要な諸性質

5. 糊の試験方点

6. 澱

7. 油
粉

戍
8. 增 量 剂

9. 防 徽 剂

10. 糊 の 調 合

11。澱粉の膨潤

12. 糊液の濃度と粘度

13. 綛

糊

14. 新しい糊材料
15. 糊調合設備

16. 糊 付 機 械

17. 新しい設㣁及び㙨械

18. 糊付蟣の自動制御

19. アメリカに扑ける糊付技術

20.あとがき 